ISSN 0258-7122

Bangladesh J. Agril. Res. 36(3) : 537-542, September 2011 Short Communication

\title{
EFFECTS OF PLANT POPULATION AND BIO-FERTILIZER ON THE GROWTH PARAMETERS OF THREE SUMMER MUNGBEAN (Vigna radiata L.) CULTIVARS
}

\author{
M.M. RANA ${ }^{1}$, A. K. M. S. H. CHOWDHURY ${ }^{2}$ AND M. S. U. BHUIYA ${ }^{3}$
}

Keywords: Mungbean, plant population, bio-fertilizer, growth.

Mungbean (Vigna radiata L.) is one of the most important pulse crops of Bangladesh. It has the potential to enrich soil through atmospheric nitrogen fixation. It can also minimize the scarcity of fodder because the whole plant or its by-products can be used as good animal feed. Besides being used as food and feed, mungbean is also used as green manuring crop to improve soil fertility. In Bangladesh, the average yield of mungbean is $0.64 \mathrm{t} / \mathrm{ha}$ (BBS, 2001), which is much lower than those of India and other countries of the world. More than $3 \mathrm{t} / \mathrm{ha}$ of seed yields have been reported in many trials in AVRDC (Lawn, 1978). Poor growth and yield of mungbean in this country is probably due to lack of appropriate agronomic practices, especially the balanced fertilization and plant population per unit area. The farmers of Bangladesh generally grow mungbean by one or zero tillage but use almost no fertilizer. Adequate supply of nitrogenous fertilizer is essential for normal growth and yield of this type of crop. But the farmers of this country can not use this type of fertilizer because of high price and often are not readily available in the market. The workers and scientists have probably found a way to overcome this problem by using bio-fertilizer. In Bangladesh, inoculation with Bradyrhizobium increased 57\% effective nodule, $77 \%$ dry mater production, $64 \%$ grain yield, and $40 \%$ hay yield over uninoculated control (Chanda et al., 1991). In the development of appropriate management practices for mungbean, plant population also plays an important role as it is one of the most important yield contributing characters (Babu and Mitra, 1989). In lower plant population, individual plant performance is better than that of higher plant population but within tolerable limit higher plant population produces higher yield/ha (Shukla and Dixit, 1996a). Therefore, optimum plant population ensures normal plant growth because of efficient utilization of moisture, light, space and nutrients, thus increases the yield of crop. Considering the above facts, the study has been undertaken to find out the effect of plant population and bio-fertilizer on the growth parameters of summer mungbean cultivars.

The experiment was conducted at the Agronomy Field Laboratory, Department of Agronomy, Bangladesh Agricultural University, Mymensingh

\footnotetext{
${ }^{1}$ Scientific Officer, Agronomy Division, BTRI, Srimangal, Moulvibazar, ${ }^{2}$ Professor Department of Agronomy, Bangladesh Agricultural University (BAU), Mymensingh, ${ }^{3}$ Professor, Department of Agronomy, BAU, Mymensingh, Bangladesh.
} 
from February to May 2004. The experimental area was characterized by noncalcareous dark grey floodplain soil. The $\mathrm{pH}$ value of the soil was 6.7 , low in organic matter and silty loam texture. Three sets of treatments were included in the experiment, which were (a) three plant populations: 30, 45, and 60 plants $/ \mathrm{m}^{2}$, (b) two inoculations: no inoculation and inoculation and (c) three summer mungbean cultivars: Barimoog-2, Barimoog-5, and Binamoog-5. The experiment was laid out in a randomized complete block design (RCBD) with three replications with inter plot spacing of $0.5 \mathrm{~m}$ and inter block spacing of 1.0 $\mathrm{m}$. The size of the unit plot was $10 \mathrm{~m}^{-2}(5.0 \mathrm{~m} \times 2.0 \mathrm{~m})$ and the total number of plots was 54 .

At the time of final land preparation, each unit plot was fertilized with $\mathrm{P}$ and K@ 10 and 15 kg/ha (BINA, 2002), respectively. N @ 12 kg/ha was applied just before sowing the seeds. The bio-fertilizer (Bradyrhizobium inoculant BINAMB-1) used in the present study was collected from the Bangladesh Institute of Nuclear Agriculture (BINA), Mymensingh. Seeds were inoculated following proper method and the uninoculated and inoculated seeds were sown in the noon and afternoon, respectively, in $25 \mathrm{~cm}$ apart rows at about $3 \mathrm{~cm}$ depth and covered with soil. At 14 DAS, a plant counter of $100 \times 100 \mathrm{~cm}$ was randomly placed in each plot and plants were counted. Thinning was done at 20 DAS to maintain the recommended plant population $/ \mathrm{m}^{2}$. Weeding, irrigation, drainage, insect control, etc. were done as when necessary. Data on growth parameters were collected by destructive plant sampling at 15-day intervals starting from 20 DAS to harvest. Five plants were harvested randomly from each plot.

Results showed that plant height did not differ significantly due to plant population up to 50 DAS but differed significantly thereafter (Table 1). Tallest plants at all the sampling dates were found in the 30 plants $/ \mathrm{m}^{2}$. At harvest, significantly tallest plant was found with 30 plants $/ \mathrm{m}^{2}(36.84 \mathrm{~cm})$, followed by 45 plants $/ \mathrm{m}^{2}(35.19 \mathrm{~cm})$ and the shortest plant was noted with 60 plants $/ \mathrm{m}^{2}$ $(33.59 \mathrm{~cm})$. The plants under higher population became smaller might be due to shortage of nutrient, water and other related component elements. The result is in agreement with Hoq and Hossain (1981), who observed significant effect of plant density on the height of mungbean.

Plant height was also significantly affected by inoculation at all the sampling dates except 20 DAS and 50 DAS (Table 2). Tallest plants at all the sampling dates were recorded under inoculated condition. Singh et al. (2004) also observed significant difference in plant height on mungbean with inoculation. This might be due to the atmospheric nitrogen fixation by the bacteria in the roots of plants in inoculated plot that ultimately enhanced plant height. 
Table 1. Effect of plant population on the growth parameters of mungbean.

\begin{tabular}{|c|c|c|c|c|c|c|c|c|c|c|c|c|c|c|c|c|c|c|c|}
\hline \multirow{2}{*}{$\begin{array}{l}\text { Number of } \\
\text { plansts } \mathrm{m}^{2}\end{array}$} & \multicolumn{5}{|c|}{ Plant height $(\mathrm{cm})$ at } & \multicolumn{5}{|c|}{ Dry matter wt $(\mathrm{g} / \mathrm{m})$ at } & \multicolumn{5}{|c|}{ Leaf Area Index (LAI) at } & \multicolumn{4}{|c|}{$\begin{array}{l}\text { Crop growth rate }\left(\mathrm{g} \mathrm{m}^{-2} \text { day }^{-1}\right) \\
\text { during }\end{array}$} \\
\hline & $\begin{array}{c}20 \\
\text { DAS }\end{array}$ & $\begin{array}{l}35 \\
\text { DAS }\end{array}$ & $\begin{array}{l}50 \\
\text { DAS }\end{array}$ & $\begin{array}{c}65 \\
\text { DAS }\end{array}$ & Harvest & $\begin{array}{c}20 \\
\text { DAS }\end{array}$ & $\begin{array}{c}35 \\
\text { DAS }\end{array}$ & $\begin{array}{c}50 \\
\text { DAS }\end{array}$ & $\begin{array}{c}65 \\
\text { DAS }\end{array}$ & Harvest & $\begin{array}{c}20 \\
\text { DAS }\end{array}$ & $\begin{array}{c}35 \\
\text { DAS }\end{array}$ & $\begin{array}{c}50 \\
\text { DAS }\end{array}$ & \begin{tabular}{c|}
65 \\
DAS
\end{tabular} & Harvest & $\begin{array}{l}20-35 \\
\text { DAS }\end{array}$ & $\begin{array}{l}36-50 \\
\text { DAS }\end{array}$ & $\begin{array}{l}51-65 \\
\text { DAS }\end{array}$ & $\begin{array}{c}66 \\
\text { DAS- } \\
\text { Harvest }\end{array}$ \\
\hline $30\left(\mathrm{P}_{1}\right)$ & 9.69 & 13.45 & 26.56 & 34.51a & 36.84 a & $2.63 c$ & 12.50c & $64.53 \mathrm{~b}$ & 179.54c & $216.37 \mathrm{c}$ & $0.03 \mathrm{c}$ & $0.16 \mathrm{c}$ & $0.57 \mathrm{c}$ & $0.90 \mathrm{c}$ & $0.99 \mathrm{~b}$ & $0.66 \mathrm{c}$ & $3.47 \mathrm{~b}$ & $7.67 \mathrm{~b}$ & $2.46 \mathrm{c}$ \\
\hline $45\left(\mathrm{P}_{2}\right)$ & 9.62 & 13.29 & 26.41 & $34.41 \mathrm{a}$ & $35.19 \mathrm{ab}$ & $3.87 \mathrm{~b}$ & $19.64 b$ & 92.16a & 215.53b & $273.82 \mathrm{~b}$ & $0.05 \mathrm{~b}$ & $0.23 \mathrm{~b}$ & $0.79 \mathrm{~b}$ & $1.12 \mathrm{~b}$ & $1.25 \mathrm{a}$ & $1.05 \mathrm{~b}$ & $4.84 \mathrm{a}$ & $8.22 \mathrm{~b}$ & $3.89 \mathrm{~b}$ \\
\hline $60\left(\mathrm{P}_{3}\right)$ & 9.33 & 12.84 & 26.08 & $31.77 \mathrm{~b}$ & $33.59 \mathrm{~b}$ & $5.17 \mathrm{a}$ & 22.96a & 98.80a & 253.57a & $334.06 \mathrm{a}$ & 0.06 a & $0.31 \mathrm{a}$ & 0.88 a & $1.19 \mathrm{a}$ & $1.30 \mathrm{a}$ & $1.19 \mathrm{a}$ & $5.06 \mathrm{a}$ & $10.32 \mathrm{a}$ & $5.37 \mathrm{a}$ \\
\hline $\begin{array}{l}\text { Level of } \\
\text { sig. }\end{array}$ & NS & NS & NS & 0.01 & 0.01 & 0.01 & 0.01 & 0.01 & 0.01 & 0.01 & 0.01 & 0.01 & 0.01 & 0.01 & 0.01 & 0.01 & 0.01 & 0.01 & 0.01 \\
\hline $\mathrm{s} \bar{x}$ & 0.2480 & 0.3516 & 0.5711 & 0.4754 & 0.6995 & 0.0600 & 0.3986 & 1.9257 & 4.5818 & 4.1938 & 0.0013 & 0.0060 & 0.0113 & 0.0154 & 0.0300 & 0.0238 & 0.1203 & 0.2528 & 0.1101 \\
\hline CV (\%) & 11.03 & 11.31 & 9.20 & 6.01 & 8.43 & 6.54 & 9.21 & 9.59 & 8.99 & 6.48 & 11.90 & 10.96 & 6.43 & 6.11 & 10.75 & 10.46 & 11.46 & 12.28 & 11.97 \\
\hline
\end{tabular}

In a column, figures having similar letter(s) or without letter do not differ significantly whereas, figures bearing dissimilar letters differ significantly. $\mathrm{P}_{1}=30$ plants $/ \mathrm{m}^{2}, \mathrm{P}_{2}=45$ plants $/ \mathrm{m}^{2}, \mathrm{P}_{3}=60$ plants $/ \mathrm{m}^{2}$, NS= Not significant. 
Table 2. Effect of bio-fertilizer on the growth parameters of mungbean.

\begin{tabular}{|c|c|c|c|c|c|c|c|c|c|c|c|c|c|c|c|c|c|c|c|}
\hline \multirow[b]{2}{*}{ Treatment } & \multicolumn{5}{|c|}{ Plant height $(\mathrm{cm})$ at } & \multicolumn{5}{|c|}{ Dry matter wt $\left(\mathrm{g} / \mathrm{m}^{2}\right)$ at } & \multicolumn{5}{|c|}{ Leaf Area Index (LAI) at } & \multicolumn{4}{|c|}{$\begin{array}{c}\text { Crop growth rate (g/m²/day) } \\
\text { during }\end{array}$} \\
\hline & $\begin{array}{c}20 \\
\text { DAS }\end{array}$ & $\begin{array}{c}35 \\
\text { DAS }\end{array}$ & $\begin{array}{c}50 \\
\text { DAS }\end{array}$ & $\begin{array}{c}65 \\
\text { DAS }\end{array}$ & Harvest & $\begin{array}{c}20 \\
\text { DAS }\end{array}$ & $\begin{array}{c}35 \\
\text { DAS }\end{array}$ & $\begin{array}{c}50 \\
\text { DAS }\end{array}$ & $\begin{array}{c}65 \\
\text { DAS }\end{array}$ & Harvest & $\begin{array}{c}20 \\
\text { DAS }\end{array}$ & $\begin{array}{c}35 \\
\text { DAS }\end{array}$ & $\begin{array}{c}50 \\
\text { DAS }\end{array}$ & $\begin{array}{c}65 \\
\text { DAS }\end{array}$ & Harvest & \begin{tabular}{|l|} 
20-35 \\
DAS
\end{tabular} & \begin{tabular}{|l}
$36-50$ \\
DAS
\end{tabular} & $\begin{array}{l}\text { 51-65 } \\
\text { DAS }\end{array}$ & $\begin{array}{c}66 \\
\text { DAS- } \\
\text { Harvest }\end{array}$ \\
\hline $\begin{array}{l}\text { Without } \\
\text { inoculation } \\
\left(\mathrm{I}_{0}\right)\end{array}$ & 9.29 & $12.29 \mathrm{~b}$ & 25.86 & $32.81 \mathrm{~b}$ & $34.33 \mathrm{~b}$ & 3.85 & $16.30 \mathrm{~b}$ & $82.41 \mathrm{~b}$ & 206.18b & $262.44 \mathrm{~b}$ & 0.05 & $0.21 \mathrm{~b}$ & 0.73 & $1.05 \mathrm{~b}$ & 1.17 & $0.83 \mathrm{~b}$ & 4.41 & $8.25 \mathrm{~b}$ & $3.75 \mathrm{~b}$ \\
\hline $\begin{array}{l}\text { Inoculation } \\
\left(\mathrm{I}_{1}\right)\end{array}$ & 9.79 & $14.09 \mathrm{a}$ & 26.84 & $34.32 \mathrm{a}$ & $36.09 \mathrm{a}$ & 3.94 & 20.43a & 87.94a & 226.25a & $287.05 a$ & 0.05 & $0.25 \mathrm{a}$ & 0.76 & $1.10 \mathrm{a}$ & 1.20 & 1.10a & 4.50 & 9.22a & $4.05 \mathrm{a}$ \\
\hline $\begin{array}{l}\text { Level of } \\
\text { sig. }\end{array}$ & NS & 0.01 & NS & 0.01 & 0.05 & NS & 0.01 & 0.05 & 0.01 & 0.01 & NS & 0.01 & NS & 0.01 & NS & 0.01 & NS & 0.01 & 0.05 \\
\hline$s \bar{x}$ & 0.2025 & 0.2871 & 0.4663 & 0.3881 & 0.5711 & 0.0490 & 0.3255 & 1.5724 & 3.7410 & 3.4243 & 0.0011 & 0.0049 & 0.0092 & 0.0126 & 0.0245 & 0.0194 & 0.0982 & 0.2064 & 0.0899 \\
\hline CV (\%) & 11.03 & 11.31 & 9.20 & 6.01 & 8.43 & 6.54 & 9.21 & 9.59 & 8.99 & 6.48 & 11.90 & 10.96 & 6.43 & 6.11 & 10.75 & 10.46 & 11.46 & 12.28 & 11.97 \\
\hline
\end{tabular}

In a column, figures having similar letter(s) or without letter do not differ significantly whereas, figures bearing dissimilar letters differ significantly. NS= Not significant 
Dry matter production significantly differed with plant population and it is seen from Table 1 that treatment having maximum plant population (60 plants $/ \mathrm{m}^{2}$ ) produced significantly highest dry matter at all sampling dates followed by 45 plants $/ \mathrm{m}^{2}$. The lowest value was recorded under minimum plant population (30 plants $\left./ \mathrm{m}^{2}\right)$. However, at harvest, the highest dry matter weight $\left(334.06 \mathrm{~g} / \mathrm{m}^{2}\right)$ was achieved at 60 plants $/ \mathrm{m}^{2}$ followed by $273.82 \mathrm{~g} / \mathrm{m}^{2}$ at 45 plants $/ \mathrm{m}^{2}$ and the lowest $216.37 \mathrm{~g} / \mathrm{m}^{2}$ from 30 plants $/ \mathrm{m}^{2}$. This finding is in agreement with the result of Trung and Yoshida (1985).

Inoculation showed its significant effect on dry matter production at all growth stages except at 20 DAS (Table 2). The higher dry matter of $287.05 \mathrm{~g} / \mathrm{m}^{2}$ was obtained from inoculated plant at final harvest.

Plant population had significant effect on LAI at all sampling dates (Table 1). The highest LAI $(0.06,0.31,0.88,1.19$, and 1.30$)$ was noted from 60 plants $/ \mathrm{m}^{2}$ followed by 45 plants $/ \mathrm{m}^{2}(0.05,0.23,0.79,1.12$ and 1.25$)$ and the lowest $(0.03$, $0.16,0.57,0.90$, and 0.99 ) from 30 plants $/ \mathrm{m}^{2}$ at 20, 35, 50, 65 DAS, and at harvest, respectively. The highest plant population produced more leaf area ultimately showing higher LAI. It is in agreement with the result of Sekhon et al. (2002).

Inoculation significantly increased the LAI at 35 DAS (0.25) and 65 DAS (1.10). It was 0.21 and 1.05 at the respective sampling dates under uninoculated condition (Table 2). This result was similar with the result of Singh et al. (2004), who observed significant difference in LAI with inoculation. The probable reason might be due to large leaf area in inoculated plant.

Crop growth rate (CGR) was affected significantly at all sampling period (Table 1) and increased with the increasing plant population and also with the age of plant. Peak period was observed at 51-65 DAS at all plant population, thereafter it declined. This result is in conformity with the result of Singh (1982). The highest CGR of 1.19, 5.06, 10.32, and $5.37 \mathrm{~g} / \mathrm{m}^{2}$ day were observed under 60 plants $/ \mathrm{m}^{2}$ and the lowest values of $0.66,3.47,7.67$ and $2.46 \mathrm{~g} / \mathrm{m}^{2}$ day were noted at 30 plants $/ \mathrm{m}^{2}$ within the period 20-35, 36-50, 51-65, and 66 DAS-harvest, respectively.

Inoculation significantly favoured CGR at all sampling duration except 3650 DAS (Table 2). It is evident that higher CGR of 1.10, 4.50, 9.22, and 4.05 $\mathrm{g} / \mathrm{m}^{2}$ day was found with inoculation and lower values of $0.83,4.41,8.25$, and $3.75 \mathrm{~g} / \mathrm{m}^{2}$ day being observed with no inoculation condition during 20-35, 3650, 51-65 and 66 DAS-harvest, respectively. The probable reason might be due to higher dry matter production with inoculated plant that ultimately showed higher CGR. 


\section{References}

Babu, K.S. and S. K. Mitra, 1989. Effect of plant density on grain yield of maize during rabi season. Madras Agric. J. 76: 290-292.

BBS (Bangladesh Bureau of Statistics). 2001. Statistical Yearbook of Bangladesh. BBS, Stat. Div., Ministry Plan., Govt. of People's Repub of Bangladesh, Dhaka. pp. 134, 135 and 672.

BINA (Bangladesh Institute of Nuclear Agriculture). 2002. Grismkalin Moongkolaiar Unnata Jat, Binamoog-2 '0' Binamoog-5 (Bangla). Folder. B1NA, Mymensingh, Bangladesh.

Chanda, M.C., M. A. Satter, A. R. M. Solaiman and A. K. Podder. 1991. Effect of Rhizobium inoculation on mungbean cultivars as affected by chemical fertilizers. Intl. Bot. Conf, 10-12 January 1991. Dhaka (Bangladesh).

Hoq, M.A. and A. Hossain. 1981. Effect of plant density on yield and yield components in mungbean. Pakistan J. Agric. Res. 2(1): 29-32.

Lawn, R.J. 1978. Yield and yield potential of mungbean (Vigna radiata) and blackgram (Vigna mungo). Proceedings of the first International Mungbean Symposium, Shanhua, Taiwan, AVRDC. pp. 24-27.

Sekhon, H.S., Guriqbal Singh, J. S. Brar and G. Singh. 2002. Effect of population density and planting geometry on the growth and yield of mungbean (Vigna radiata L. Wilczek) genotypes. Environ. Ecol. 20(4): 897-901.

Shukla, S.K. and R. S. Dixit. 1996a. Nutrient and plant population management in summer greengram (Phaseolus radiatus). Indian J. Agron. 41(1): 78-83.

Singh, G.B. 1982. Effect of seasonal changes on growth parameters of greengram (Vigna radiata L. Wilczek). Indian J. Plant Physiol. 25(4): 382-389.

Singh, M., H. S. Sekhon, J. Singh, Manpreet Singh and Jagrup Singh. 2004. Response of summer mungbean (Vigna radiata L. Wilczek) genotypes to different phosphorus levels. Environ. Ecol. 22(1): 13-17.

Trung, B.C. and S. Yoshida. 1985. Influence of planting density on the nitrogen nutrition and grain productivity of mungbean. Japanese J. Crop Sci. 54(3): 166-172. 